\title{
Efektivitas Penggunaan Alat Peraga Kartu Bilangan Untuk Meningkatkan Hasil Belajar Siswa Kelas II SD Dalam Memahami Lambang Bilangan
}

\author{
Samsul Maarif \\ SD Negeri Kubangsari 01 \\ ihdamaarif@gmail.com
}

\section{Article History}

received 3/12/2020

\begin{abstract}
Abstrak
The use of the Number Card teaching aid in Class II SDN Kubangsari 01, in general, has the aim of improving student learning outcomes in MTK mupel in writing number symbols up to 900. The research method used is experimental technique. Based on the experimental results of the average student learning outcomes before being given treatment in the form of learning using number card props, the average value of these students (pretest) was only 50.33 and after being given treatment in the form of learning using number card props the average value The average of these students (posttest) became 75.00 with a KKM of 60. This result means that the use of the Number Card teaching aids can improve the learning outcomes of MTK mupel students, especially the number symbol material in Class II SDN Kubangsari 01.
\end{abstract}

Keywords: number cards, learning outcomes

\begin{abstract}
Penggunaan alat peraga Kartu Bilangan pada Kelas II SDN Kubangsari 01, secara umum memiliki tujuan untuk meningkatkan hasil belajar peserta didik pada mupel MTK dalam menulis lambang bilangan sampai dengan 900. Metode penelitian yang digunakan adalah Teknik eksperimen. Berdasarkan hasil eksperimen dari rata-rata hasil belajar siswa sebelum diberikan perlakuan berupa pembelajaran menggunakan alat peraga kartu bilangan, nilai rata-rata peserta didik tersebut (pretest) hanya sebesar 50,33 dan setelah diberikan perlakuan berupa pembelajaran menggunakan alat peraga kartu bilangan nilai rata-rata peserta didik tersebut (posttest) menjadi 75,00 dengan KKM yaitu 60. Hasil ini berarti menunjukan bahwa penggunaan alat peraga Kartu Bilangan dapat meningkatkan hasil belajar peserta didik mupel MTK khususnya materi lambang bilangan di Kelas II SDN Kubangsari 01.
\end{abstract}

Kata kunci: kartu bilangan, hasil belajar

Social, Humanities, and Education Studies (SHEs): Conference Series https://jurnal.uns.ac.id/shes 


\section{PENDAHULUAN}

Penggunaan Alat peraga dapat membantu peserta didik lebih mudah memahami konsep yang diajarkan, selain itu juga dapat menghindari keterbatasan berfikir peserta didik. Menurut Gagne dan Briggs (dalam sundayana rostina 2013: 15) "Secara implisit menyatakan bahwa, media pembelajaran meliputi alat yang secara fisik digunakan untuk menyampaikan isi materi pengajaran yang antara lain buku, tape-recorder, kaset, video camera, film,(gambar bingkai), foto, gambar, grafik, televisi, dan computer". Dengan kata lain, media adalah komponen sumber belajar atau wahana fisik yang mengandung materi instruksional di lingkungan murid yang dapat merangsang murid untuk belajar.

Guru sebagai pelaksana dalam proses pembelajaran di lembaga pendidikan, seyogyanya dapat memenuhi kebutuhan dan kemampuan siswa dalam suatu proses pelajaran yang menarik, kreatif dan menantang guna meningkatakan kemampuan berpikir realistis khususnya pada pembelajaran matematika. Menurut Arsyad (2016:9) "alat peraga adalah media alat bantu pembelajaran dan segala macam benda yang digunakan untuk memperagakan materi pelajaran”. Dengan adanya alat peraga, peserta didik mudah memahami materi yang diajarkan, selain itu dengan adanya alat peraga yang dapat dilihat, dipandang, dirasakan dan diraba oleh peserta didik akan membuat pembelajaran menjadi lebih bermakna. Benda-benda nyata yang dijadikan alat perantara pengetahuan disebut juga sebagai media pembelajaran, salah satu media yang digunakan dalam pendekatan matematika realistik adalah kartu bilangan. Kartu bilangan adalah kertas karton yang bertuliskan angka-angka yang sesuai dengan tujuan pembelajaran.

Masalah-masalah nyata dari kehidupan sehari-hari digunakan sebagai titik awal pembelajaran matematika untuk menunjukkan bahwa matematika sebenarnya dekat dengan kehidupan sehari-hari. Pembelajaran matematika sangat penting untuk dipelajari karena ilmu matematika merupakan ilmu pasti yang teruji kebenarannya. Matematika juga selalu digunakan dalam kehidupan sehari-hari untuk memecahkan suatu permasalahan dalam kehidupan sehari-hari. Pembelajaran matematika disekolah dasar pada umumnya masih bersifat abstrak, sehingga dibutuhkannya pembelajaran yang dikaitkan dengan kondisi nyata peserta didik.

Berdasarkan observasi yang telah dilakukan pada peserta didik kelas II SDN Kubangsari 01 pada saat pembelajaran mupel Matematika materi tentang menulis lambang bilangan, diperoleh data mengenai hasil belajar peserta didik dalam menulis lambang bilangan dari 0 - 999 hanya sekitar 33\% dari jumlah peserta didik kelas II SDN Kubangsari 01 yang memperoleh ketuntasan dengan hasil diatas KKM 60. Dalam hal ini guru saat mengajar menggunakan buku panduan guru dari kemendikbud yang hanya memakai alat bantu berupa kubus satuan dalam menyampaikan materi tentang menulis lambang bilangan. Melihat kasus tersebut maka dibutuhkannya alat peraga yang menarik, sederhana, serta mampu meningkatkan pemahaman dan kemampuan peserta didik dalam mupel matematika tentang materi menulis lambang bilangan dari 0 sampai dengan 999.

Rumusan masalah dalam artikel ini yaitu "Apakah penggunaan alat peraga kartu bilangan dapat meningkatkan hasil belajar peserta didik kelas II pada mupel Matematika tentang materi menulis lambang bilangan di SDN Kubangsari 01 ?" Menurut Novianti $(2014,6)$ media kartu bilangan adalah media kartu bergambar yang di dalamnya terdapat bilangan atau angka, sebagai salah satu media visual yang mudah dimengerti dan dipahami anak. Oleh karena itu dengan penggunaan media kartu bilangan dalam proses pembelajaran Matematika akan dapat memberikan pengaruh terhadap peningkatan hasil belajar mengenal bilangan pada anak, karena sesuai dengan tahap perkembangan anak pada umumnya di mana pada masa itu anak berada pada tahap pra operasional konkrit.

Indikator keefektifan pembelajaran ditinjau beberapa aspek: 
1. Ketuntasan hasil belajar murid

2. Aktifitas murid dalam kegiatan pembelajaran

3. Respon murid dalam belajar

Berdasarkan rumusan masalah diatas, maka tujuan dilakukannya penelitian ini adalah untuk mengetahui sejauh mana tingkat keberhasilan penggunaan alat peraga kartu bilangan untuk meningkatkan hasil belajar peserta didik kelas II SDN Kubangsari 01 Kecamatan Ketanggungan Kabupaten Brebes.

\section{METODE}

Secara umum metode penelitian diartikan sebagai cara ilmiah untuk mendapatkan data dengan tujuan dan kegunaan tertentu. Menurut Sugiyono (2009:6), metode penelitian adalah cara ilmiah untuk mendapatkan data yang valid dengan tujuan dapat ditemukan, dikembangkan, dan dibuktikan, suatu pengetahuan tertentu sehingga pada gilirannya dapat digunakan untuk memahami, memecahkan, dan mengantisipasi masalah dalam bidang pendidikan.

Berdasarkan uraian tersebut, maka metode yang digunakan dalam penelitian ini adalah metode eksperimen. Sugiyono (2006:80, dalam Soendari), menyatakan bahwa Eksperimen adalah metode penelitian yang digunakan untuk mencari pengaruh perlakuan tertentu terhadap yang lain dalam kondisi yang terkendalikan. Penelitian ini merupakan penelitian eksperimen yaitu jenis One-Group Pretest-Posttest Design. Dalam penelitian ini, hasil perlakuan dapat di ketahui lebih akurat, karena dapat membandingkan dengan keadaan sebelum diberi perlakuan (treatment).

Desain penelitian yang dilakukan adalah sebagai berikut :

$$
\mathrm{O}_{1} \mathrm{X} \mathrm{O}_{2}
$$

Sumber: (sugiyono,2017:110-111)

Keterangan :

O1 : Tes awal sebelum diberikan perlakuan (pretest)

$\mathrm{O}_{2}$ : Tes akhir setelah diberikan perlakuan (posttest)

$X$ : Perlakuan yang diberikan

Model eksperimen ini melalui tiga Langkah yaitu :

a. Memberikan pretest untuk mengukur variabel terikat (Hasil belajar matematika) sebelum perlakuan dilakukan.

b. Memberikan perlakuan kepada kelas subjek penelitian dengan menggunakan alat peraga pembelajaran kartu bilangan.

c. Memberikan posttest untuk mengukur variabel terikat setelah perlakuan dilakukan.

\section{HASIL DAN PEMBAHASAN}

Penelitian ini merupakan eksperimen yang pembelajarannya menggunakan alat peraga. Penelitian ini dilakukan dengan tujuan untuk mengetahui hasil belajar peserta didik yang pembelajarannya menggunakan alat peraga kartu bilangan dengan peserta didik yang pembelajarannya sebelum menggunakan alat peraga kartu bilangan.

Untuk mengetahui tingkat penguasaan murid terhadap materi yang telah diajarkan dengan menggunakan media Kartu bilangan, guru perlu menyusun suatu tes yang berdasarkan tujuan pembelajaran yang akan dicapai. Tes tersebut kemudian diberikan kepada siswa. Penskoran hasil tes murid menggunakan skala bebas yang tergantung dari bobot butir soal tersebut. Tes dalam penelitian dilakukan dengan menggunakan pretest dan posttest:

a. Pretest

Pretest ini dilakukan untuk mengetahui apakah sampel penelitian merupakan sampel yang berdistribusi normal sehingga hasil penelitian yang diharapkan benar - benar merupakan dampak dari perlakuan yang diberikan. 
b. Posttest

Soal tes akhir ini adalah bahan-bahan pelajaran yang terpenting, yang telah diajarkan kepada para peseta didik, naskah tes akhir dibuat sama dengan naskah tes awal. Dengan demikian dapat diketahui apakah tes akhir lebih baik, sama, ataukah lebih jelek dari pada hasil tes awal. Jika hasil tes akhir itu lebih baik dari pada tes awal, maka dapat diartikan bahwa program pengajaran telah berjalan dan berhasil dengan sebaik-baiknya.

Teknik pengumpulan data yang digunakan dalam penelitian ini adalah tes awal dan tes akhir, adapun langkah-langkah pengumpulan data yang akan dilakukan sebagai berikut:

1. Tes Awal (Pretest)

Tes awal dilakukan sebelum treatment, pretest dilakukan untuk mengetahui kemampuan yang dimiliki oleh peserta didik sebelum digunakan pembelajaran dengan menggunakan alat peraga kartu bilangan.

2. Pemberian Perlakuan (Treatment)

Dalam hal ini peneliti menggunakan pembelajaran dengan alat peraga kartu bilangan terhadap hasil belajar matematika pada murid kelas II SD Negeri Kubangsari 01 Kecamatan Ketanggungan Kabupaten Brebes.

3. Tes Akhir (Posttest)

Setelah treatment, tindakan selanjutnya adalah posttest untuk mengetahui penggunaan pembelajaran dengan media kartu bilangan. Dengan demikian dapat diketahui apakah tes akhir lebih baik, sama, ataukah lebih jelek dari pada hasil tes awal. Jika hasil tes akhir itu lebih baik dari pada tes awal, maka dapat diartikan bahwa program pengajaran telah berjalan dan berhasil dengan sebaik-baiknya.

Jumlah subjek dalam penelitian ini adalah 15 peserta didik. Dari subjek tersebut diperoleh data observasi hasil belajar peserta didik dalam pembelajaran Matematika kelas II SDN Kubangsari 01 dengan menggunakan alat peraga kartu bilangan pada setiap siklus yang telah diolah dan disajikan pada tabel berikut ini:

Tabel1. Hasil belajar peserta didik dalam tiap siklus

\begin{tabular}{|c|c|c|c|}
\hline \multirow{2}{*}{ No } & \multirow{2}{*}{ Nama } & \multicolumn{2}{|c|}{ Nilai } \\
\hline & & Pretest & Posttest \\
\hline 1 & Ahmad Dhafi Alfatih & 45 & 70 \\
\hline 2 & Aira Tungga Dewi & 60 & 80 \\
\hline 3 & Akifa Dzahratu Sita & 45 & 75 \\
\hline 4 & Alisha Khaira Wilda & 60 & 90 \\
\hline 5 & Atiqah Az Zahra & 60 & 85 \\
\hline 6 & Defan Nur Fajar & 40 & 55 \\
\hline 7 & Devan Adlu Yusuf & 50 & 80 \\
\hline 8 & Dwi Nazwa Alifa & 45 & 75 \\
\hline 9 & Nurhayah Falabibah & 40 & 80 \\
\hline 10 & Reva Eviyana Kalyca & 45 & 75 \\
\hline 11 & Ririn Komalasari & 65 & 90 \\
\hline 12 & Siti Halimatus Sadiyah & 50 & 70 \\
\hline 13 & Sofi Novelia Putri & 45 & 70 \\
\hline 14 & Taufik Hilmawan & 60 & 75 \\
\hline 15 & Trisno & 45 & 55 \\
\hline \multirow{2}{*}{\multicolumn{2}{|c|}{$\begin{array}{c}\text { Jumlah } \\
\text { Rata-rata }\end{array}$}} & 755 & 1125 \\
\hline & & 50,33 & 75 \\
\hline \multicolumn{4}{|c|}{$\mathrm{KKM}=60$} \\
\hline
\end{tabular}


Ketuntasan klasikal mengalami peningkatan, pada pre test hanya terdapat 5 anak yang sudah tuntas dari 15 anak dengan nilai rata-rata 50,33 , tetapi pada post test bertambah menjadi 13 anak yang sudah tuntas dengan Kriteria Ketuntasan Minimal (KKM) sebesar 60. Persentase ketuntasan klasikalnya meningkat, jika pada saat pretest sebelum dilakukan perlakuan penggunaan alat peraga kartu bilangan hanya $33,33 \%$ maka pada posttest setelah dilakukan perlakuan penggunaan alat peraga kartu bilangan menjadi 86,66\%. Dari Tindakan tersebut dapat dipastikan bahwa penggunaan alat peraga kartu bilangan pada pembelajaran Matematika kelas II SDN Kubangsari 01 materi menulis lambang bilangan dapat meningkatkan hasil belajar peserta didik. Hal ini sesuai dengan konsep atau teori yang diungkap oleh Ruseffendi (1984, h. 384) menyatakan, alat peraga matematika itu berguna untuk

1) Supaya anak-anak lebih besar minatnya,

2) Supaya anak-anak dapat dibantu daya tiliknya sehingga lebih mengerti dan lebih besar daya ingatnya,

3) Supaya anak-anak dapat melihat hubungan antara ilmu yang dipelajarinya dengan alam sekitar.

Secara umum, Sadiman (dalam Sundayana, 2014, h, 7) menyatakan,

a. Alat peraga mempunyai fungsi.

b. Memperjelas pesan agar tidak terlalu verbalisme.

c. Mengatasi keterbatasan ruang, waktu, tenaga dan daya indera.

d. Menimbulkan gairah belajar, interaksi lebih langsung antara siswa dengan sumber belajar.

e. Pembelajaran dapat lebih menarik.

f. Sikap positif siswa terhadap materi pembelajaran dapat ditingkatkan.

Berdasarkan pendapat di atas, dapat disimpulkan bahwa alat peraga berfungsi untuk memperjelas konsep yang dipelajari karena konsep-konsep abstrak tersajikan dalam bentuk konkret, sehingga siswa dapat lebih mudah memahami konsep yang dipelajari. Memang benar adanya dengan penggunaan alat peraga berupa kartu bilangan peserta didik akan lebih mudah memahami materi khususnya menulis lambang bilangan sampai dengan 999. Dengan adanya alat bantu kartu bilangan tersebut yang membuat cara berfikir peserta didik lebih luas, sehingga peserta didik dapat memahami cara penulisan lambang bilangan sampai dengan 999 dengan benar. Berdasarkan hal tersebut dapat diketahui bahwa hasil belajar peserta didik meningkat setelah diberikan perlakuan dengan menggunakan alat peraga kartu bilangan.

Hasil pengamatan aktivitas murid dalam pembelajaran menulis lambang bilangan dengan menggunakan alat peraga kartu bilangan pada murid kelas II SD Negeri Kubangsari 01 menunjukkan bahwa telah memenuhi kriteria aktif karena sesuai dengan indikator aktivitas murid bahwa aktivitas murid dikatakan berhasil / efektif jika sekurang - kurangnya $75 \%$ murid terlibat aktif dalam proses pembelajaran. Hasil analisis data observasi aktivitas murid rata - rata persentase frekuensi aktivitas murid dalam pembelajaran menulis lambang bilangan dengan menggunakan alat bantu kartu bilangan dengan hasil observasi yaitu, sebelum perlakuan menggunakan kartu bilangan hanya sekitar 55\% siswa yang terlihat aktif. Dan setelah mendapat perlakuan berupa pembelajaran menggunakan alat peraga kartu bilangan tingkat keaktifan siswa meningkat menjadi $90 \%$. Hal ini sesuai dengan penelitian yang di lakukan oleh Emy Wahyu (2016), Rata-rata persentase aktivitas siswa 84,18\% apabila di kaitkan dengan kriteria aktivitas siswa yaitu 90\% maka aktivitas siswa mencapai kriteria aktif. Sehingga dapat disimpulkan bahwa murid aktif mengikuti proses pembelajaran matematika materi menulis lambang bilangan melalui penggunaan alat peraga kartu bilangan di kelas II SD Negeri Kubangsari 01 Kecamatan Ketanggungan Kabupaten Brebes. Berdasarkan hasil data respon murid terhadap pelaksanaan pembelajaran melalui alat peraga kartu bilangan menunjukkan bahwa rata - rata 100\% murid 
menyatakan suka belajar Matematika; $85 \%$ murid menyatakan senang belajar menulis lambang bilangan dengan menggunakan alat peraga kartu bilangan, dan 100\% murid menyukai belajar matematika menulis lambang bilangan dengan menggunakan alat peraga kartu bilangan, serta $90 \%$ murid menyatakan bersemangat belajar menulis lambang bilangan dengan menggunakan alat peraga kartu bilangan. Dengan demikian menurut kriteria keefektifan, murid telah merespon positif pelaksanaan pembelajaran menulis lambang bilangan bilangan dengan menggunakan alat peraga kartu bilangan.

\section{SIMPULAN}

Berdasarkan hasil penelitian, dapat disimpulkan bahwa terdapat perbedaan data hasil belajar peserta didik sebelum diberikan perlakuan dalam pembelajaran dengan menggunakan alat peraga kartu bilangan dengan hasil belajar peserta didik setelah diberikan perlakuan dalam pembelajaran dengan menggunakan alat peraga kartu bilangan, terbukti dari hasil analisis data hasil belajar peserta didik sebelum dan sesudah pembelajaran dengan penggunaan alat peraga kartu bilangan menunjukkan bahwa adanya peningkatan kriteria ketuntasan yaitu dari 33,33 \% menjadi 86,66 \%. Hal ini berarti bahwa pembelajaran dengan penggunaan alat peraga kartu bilangan dapat membantu peserta didik kelas II SDN Kubangsari 01 Kecamatan Ketanggungan Kabupaten Brebes untuk mencapai kriteria ketuntasan minimal pada mupel MTK materi menulis lambang bilangan.

\section{DAFTAR PUSTAKA}

Arsyad, A. 2009. Media pembelajaran. Jakarta: PT. Grafindo Persada. Arsyad. (2003). Media Pembelajaran di SD. Jakarta : Rajawali Press.

Hamdani. (2011). Strategi Belajar Mengajar. Bandung: Pustaka Setia.

Hanafiah, dan Cucu Suhana. 2009. Konsep Strategi Pembelajaran. Bandung: PT Refika aditama

Nyimas Aisyah. 2007. Pengembangan Pembelajaran Matematika SD. Jakarta: Direktorat Jenderal Pendidikan Tinggi Departemen Pendidikan Nasional.

Rusma. 2015. Pembelajaran tematik terpadu. Jakarta: PT Raja Grafindo persada.

Sundayana, rostina. 2013. Media dan alat peraga dalam pembelajaran matematika. Bandung: Alfabeta. 